\title{
Modelling spatio-temporal variability of Mytilus edulis (L.) growth by forcing a dynamic energy budget model with satellite-derived environmental data
}

\author{
Yoann Thomas ${ }^{a,}{ }^{*}$, Joseph Mazuriéb ${ }^{b}$ Marianne Alunno-Bruscia ${ }^{a}$, Cédric Bacher ${ }^{c}$, Jean-François \\ Bouget $^{b}$, Francis Gohin ${ }^{c}$, Stéphane Pouvreau ${ }^{a}$ and Caroline Struski ${ }^{d}$
}

\begin{abstract}
a Ifremer, Laboratoire Physiologie et Écophysiologie des Mollusques Marins, 11 Presqu'île du Vivier, 29840 Argenton-en-Landunvez, France

${ }^{\mathrm{b}}$ Ifremer, Laboratoire Environnement Ressource Morbihan Pays de Loire, 12, rue des résistants, BP 86, 56740 La Trinité/Mer, France

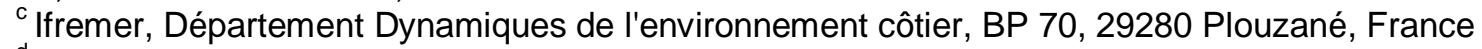

d Ifremer, Laboratoire Environnement Ressource Finistère Bretagne Nord, 2bis, rue Grout St Georges, BP 46, 35402 Saint-Malo Cedex, France
\end{abstract}

*Corresponding author :Y. Thomas, email address : yothomas@ifremer.fr

\begin{abstract}
:
In order to assess the potential of various marine ecosystems for shellfish aquaculture and to evaluate their carrying capacities, there is a need to clarify the response of exploited species to environmental variations using robust ecophysiological models and available environmental data. For a large range of applications and comparison purposes, a non-specific approach based on 'generic' individual growth models offers many advantages. In this context, we simulated the response of blue mussel (Mytilus edulis L.) to the spatio-temporal fluctuations of the environment in Mont Saint-Michel Bay (North Brittany) by forcing a generic growth model based on Dynamic Energy Budgets with satellitederived environmental data (i.e. temperature and food). After a calibration step based on data from mussel growth surveys, the model was applied over nine years on a large area covering the entire bay. These simulations provide an evaluation of the spatio-temporal variability in mussel growth and also show the ability of the DEB model to integrate satellite-derived data and to predict spatial and temporal growth variability of mussels. Observed seasonal, inter-annual and spatial growth variations are well simulated. The large-scale application highlights the strong link between food and mussel growth. The methodology described in this study may be considered as a suitable approach to account for environmental effects (food and temperature variations) on physiological responses (growth, reproduction) of filter feeders in varying environments. Such physiological responses may then be useful for evaluating the suitability of coastal ecosystems for shellfish aquaculture.
\end{abstract}

\section{Research highlights}

- We used satellite data (temperature, Chl-a) with a dynamic energy budget model. $>$ The model correctly describes the observed spatio-temporal variability in mussel growth. A large-scale application highlights the strong link between food and mussel growth. The methodology developed may be useful for evaluating the suitability of coastal ecosystems for shellfish aquaculture.

Keywords: Mussel; DEB; SeaWifs; Aquaculture; site selection; resource management 
Spatial planning provides a structural framework for activities in coastal areas, but requires support in important aspects of decision-making (Douvere and Ehler, 2009; Halpern et al., 2008). As part of the ecosystem-based approach to aquaculture, several reports have emphasized the interest of applying geographic information systems (GIS) as part of such an approach (Aguilar-Manjarrez et al., 2010; Soto et al., 2008). There is therefore a demand from institutions, especially at the European scale, for tools that can help optimize aquaculture practice, determine ecosystem carrying capacity, monitor water quality, restructure existing shellfish culture areas, assess maximum yield, select new potential sites and/or to assess fishing effort. The implementation of this type of tool requires an in-depth understanding of interactions between cultivated species and their environment (Dowd, 2005) in order to evaluate the carrying capacity of coastal areas, maintain cultivated species production and reduce ecological impacts.

During the last decade, an increasing interest has been taken in the carrying capacity of shellfishgrowing areas (McKindsey et al., 2006). Investigations have been conducted through field studies comparing growth capacities in several coastal ecosystems (Waite et al., 2005), or by modelling approaches (Duarte et al., 2003; Jiang and Gibbs, 2005; Sara and Mazzola, 2004). Nevertheless, there is still a need for a generic modelling approach to clarify the response of bivalves to environmental variability, i.e. a model that would be valid and easy to implement at any site, for any species and that could be used over time. Such modelling tools will allow a better understanding of shellfish growth variability, which mainly depends on physico-chemical conditions (e.g. temperature) and food supply.

Different bio-energetic models have been developed to explain the growth of bivalves according to the environmental conditions, i.e. temperature and food supply. Most of these are net production models based on the Scope for Growth (SFG) concept (Bayne, 1976); they use a detailed empirical sequence of steps for nutrition and resource allocation, based on allometric relationships, and assume that the assimilated energy is immediately available for maintenance, the remainder being used for growth or stored as reserves (Bacher et al., 1991; Barillé et al., 1997; Grant and Bacher, 1998; Schneider, 1992; Scholten and Smaal, 1998). Other, more mechanistic, models developed for bivalves are based on the dynamic energy budget (DEB) theory (Kooijman, 1986; Kooijman, 2010), which has been successfully applied to several marine species (Bacher and Gangnery, 2006; Bourlès et al., 2009; Cardoso et al., 2006; Casas and Bacher, 2006; Pouvreau et al., 2006; Ren and Ross, 2005; Rico-Villa et al., 2010; Rosland et al., 2009; Ross and Nisbet, 1990; Van Haren and Kooijman, 1993). DEB models do not use empirical allometric relationships, but simply state that feeding is proportional to surface area, whereas maintenance is scaled according to structural body volume. More generally, DEB theory proposes a generic energy budget approach that assumes common physiological processes among species and life stages via a set of parameters, the only difference among species lying in the values of the parameters. These promising arguments and recent successful applications led us to use the DEB model to estimate the growth response of blue mussel Mytilus edulis to a natural trophic gradient observed in a shellfish farming bay in North Brittany. Trophic resources are usually represented by the phytoplankton concentration (expressed as chlorophyll-a or cell concentration), because this resource seems able to explain most of the observed bivalve growth (Bacher and Gangnery, 2006; Bourlès et al., 2009; Pouvreau et al., 2006; Rosland et al., 2009). As an initial approach, chlorophyll-a may therefore be considered as a relevant descriptor of the trophic resource because it correlates with the phytoplankton biomass.

The method used in the present study consists of coupling a dynamic energy budget approach with environmental data extracted from satellite images (i.e. chlorophyll-a concentration and temperature). Such data have the advantage over traditional measurements of being inexpensive, spatially extensive, automatically repeated in time and validated, i.e. well-correlated with discrete field measurements. Remote sensing of ocean-colour is a powerful technology, but few applications devoted to aquaculture have yet been developed (IOCCG, 2009a). Since the launch of the Sea-Viewing Wide Field-of-view Sensor (SeaWIFS) in 1997, a considerable data set has been collected from satellites (e.g. chlorophyll-a concentration, temperature and turbidity). These data have been shown to be very useful for phytoplankton monitoring in coastal waters (Gohin et al., 2003; Heim et al., 2005; Rivas et al., 2006). Satellite-derived chlorophyll-a concentration and particulate inorganic matter (PIM) have also been used for forcing and validating a biogeochemical model of the Bay of Biscay (Huret et al., 2007). 
The objective of the present study is to simulate the growth and reproduction of the blue mussel (Mytilus edulis, L.) in response to spatio-temporal fluctuations of the environment (i.e. trophic resources, temperature), using an individual growth model based on Dynamic Energy Budgets (DEB) and integrating satellite-derived chlorophyll-a concentration and temperature data as forcing variables. Mont Saint-Michel Bay, one of the major shellfish aquaculture areas in France, was chosen as a study site. Numerous datasets collected on mussel growth and environmental conditions over many years are available for this site. After a model calibration step based on the monitoring of mussel growth over several years and several different locations, we applied our model to a broader area to assess the spatio-temporal variability of mussel growth and the suitability of new areas for mussel cultivation.

\section{Methods}

\subsection{Study site and mussel culture}

Mont Saint-Michel Bay (MSMB) is a large sedimentary enclave $\left(500 \mathrm{~km}^{2}\right.$ with $240 \mathrm{~km}^{2}$ of inter-tidal area), opening on the English Channel (Figure 1). The mean depth is $12 \mathrm{~m}$. Due to strong tidal currents, the water column is well mixed with no vertical stratification. MSMB supports a high level of shellfish production. More than 10000 tons of saleable mussels are produced annually on poles in the bay, in addition to 5000 tons of Pacific oysters (Crassostrea gigas Th.) and 1500 tons of flat oysters (Ostrea edulis L.).

The cultivation of mussels on poles follows four successive phases: (1) natural collection of mussel seed on ropes between March and May (no recruitment occurs in MSMB, so seed collection is made in other ecosystems and the seeded ropes are imported); (2) pole stocking with seeded ropes that are wrapped around the poles starting in March; (3) growing period of mussels on poles for ca. one and a half years; and (4) harvest, between June and December of the year following recruitment. In this large rearing area of around 1000 ha (Figure 1), there are ca. 350000 poles. Producers are faced with both inter-annual and spatial differences in mussel growth. For instance, growth gradients have been observed from the coast to the open sea and in the west-east direction (Mazurié et al., 2005). While the coast-offshore gradient can be largely explained by the tide inducing a gradient in immersion time (Baird, 1966; Seed, 1976), the west-east gradient in mussel growth is probably explained by differences in food concentration (Cugier et al., 2010a).

\subsection{Mussel growth data}

Growth data were collected in five sites of the farming area from west (site A) to east (site E) in the bay (Figure 1). Samples were taken at a constant depth, corresponding to an average immersion time of $95 \%$, and concerned mussels grown according to two cultivation techniques. From 2003 to 2006, mussels were reared in bags. In 2004 and 2006, data were obtained for both mussels in bags and mussels grown on poles. Thus, data from a total of 23 growth surveys were used in this study (Table 1). The bag survey provides standardized rearing conditions for mussels, especially with a standardized initial number of mussels per bag. The pole survey represents authentic rearing conditions with uncontrolled densities (i.e. number of mussels per pole), that were probably different between sites, depending on the initial density on ropes, mortality rate or falling during storms.

For the bag survey (2003-2006), 200 mussels from a common initial pool were randomly distributed in plastic nets (mesh size: 9 to $15 \mathrm{~mm}$; volume $\approx 4 \mathrm{I}$ ). At the beginning of each survey, bags were tied to a pole at each station. Every month or two months, one bag was collected, sampled and analyzed. Details on sampling procedures are given in Table 1. For the professional survey in 2004, three poles were totally harvested at each station every two months, and subsamples were then collected and analyzed; in 2006, mussels were directly sampled from the poles. Thirty mussels from the bag surveys were measured for shell length $(\mathrm{L}, \mathrm{cm})$ and weighed (dry flesh mass, DFM, g). For the growth surveys on poles, sampling was conducted from April to October 2004 and from April to November 2006. Shell length was measured individually on sub-sample of 100 individuals and the mean dry flesh mass was estimated on a pool of 30 mussels. 


\subsection{Satellite data}

For the present work, satellite chlorophyll-a and temperature were collected every day from March 1998 to March 2007 at the scale of the whole of MSMB (http://cersat.ifremer.fr/data/view/nausicaa).

Seawater surface temperature data were obtained from NOAA-18 satellite measurements (night temperatures) at a daily step. Since very low differences were measured between locations, a single profile was used for forcing the DEB model.

The SeaWIFS reflectance, or the normalized radiance leaving the water, from which it is derived, was used to estimate the chlorophyll-a (Chl-a) concentration, based on the OC4 algorithm (Gohin et al., 2002; O'Reilly et al., 1998). Chl-a data were extracted daily at midnight from SeaWIFS reflectance data at a $1-\mathrm{km}^{2}$ resolution. Only periods without strong nebulosity contain useful information; a specific merging method was thus applied to extract daily information (Saulquin et al., 2010). Satellite Chl-a concentrations have already been validated against in situ measurements in different locations including the MSMB (Gohin et al., 2008).

\subsection{DEB model}

The dynamic energy budget model used was developed on the basis of DEB theory (Kooijman, 2010). The dynamics of growth and reproduction can be fully described with equations that describe the dynamics of the energy reserve $E$, the dynamics of the energy allocated to the structural body volume $E_{V}$, and the storage and use of the energy allocated to development (complexity acquisition before sexual maturity) and reproduction $E_{R}$. We only provide the main equations that we used to simulate mussel growth (Table 2). For a full description of the equations, see Rosland et al. (2009) and van der Meer et al. (2006). The DEB parameters used in the present study come from Rosland et al. (2009). Only the shape coefficient $\delta_{V}$ and the half-saturation coefficient $X_{K}$ are calibrated (see2.6).

As a first approximation, spawning was induced by a critical gonado-somatic index (GI, \%), defined as the ratio between the gonad mass and the total flesh mass, and a minimal temperature threshold $T_{\mathrm{S}}$. When these two thresholds are attained, the reproductive buffer $E_{R}$ is totally emptied. An average $\mathrm{Gl}$ and a temperature threshold $T_{S}$ for spawning were adjusted by comparing observed and predicted spawning events. The observations of spawning events were deduced from the losses of dry flesh mass measured during each survey of this study.

\subsection{Growth simulations}

Growth simulations were performed with MatLab ${ }^{\circledR}$ software (The MathWorks ${ }^{\mathrm{TM}}$, Inc. USA). Initial values of the state variables were derived from field measurements of seed mussels. Initial $L$ and DFM were $0.75 \mathrm{~cm}$ and $1.4 .10^{-3} \mathrm{~g}$, respectively. Due to the very low initial size, the reproductive buffer $E_{R}$ was considered to be empty at the beginning of the simulations. Initial DFM was then distributed between the structural volume $E_{V}$, and storage $E$. Energy allocated to these two compartments was firstly constrained by the initial $L$ and then energy allocated to $E_{V}$ was calculated according to equation (10) (Table 2). The remainder was allocated to $E$ according to equation (9) (Table 2).

\subsection{Calibration step}

Calibration was carried out on the 23 available datasets (Table 1). Mussel growth was simulated over two years starting from 15 March of the year before the growth study started, which corresponds to the date when new seeds are stocked on poles in MSMB. In our experiments, the mussels were reared for one year in site $A$ and dispatched in the 5 sites the second year of rearing. Then, the environmental forcing variables used for the simulations were the same for all sites until the beginning of the second year and correspond to site A conditions. Afterwards, the satellite data points closest to each site were used. Initial conditions are considered to be homogenous and correspond to the seed mussel characteristics described above.

The parameters $X_{K}$ and $\delta_{V}$ were calibrated on the 23 growth curves, according to the Nelder and Mead simplex (for more details see DEBtool manual index.html in the subdirectory 'manual' of DEBtool at http://www.bio.vu.nl/thb/deb/deblab/). The calibration was performed on both: shell length and DFM. The calibration on length, giving the best adjustment, was retained. The goodness-of-fit of the model was evaluated by linear regression between the observations $(X)$ and 
the simulations $(Y)$, excluding the first values. This model was tested against the model $Y=X$ at an $\alpha$ error threshold of $5 \%$. The $\mathrm{R}^{2}$ coefficient of determination was used to indicate the amount of the variance explained by the model.

\subsection{Large scale application}

As a large-scale application, we made a simulation of mussel growth in the whole of MSMB and an extension northward, outside the existing mussel farming area, up to the Chausey Islands. Growth was simulated at each of the 584 points documented for Chl-a and covering the whole of MSMB at a daily time step. Nine years of growth were simulated from 1998 to 2006, resulting in nine growth profiles. Each simulation started and ended on 15 March, which corresponds to the date when new seeds are stocked on poles in MSMB. Simulations were performed with an immersion time factor of 1 for the oceanic sectors and an immersion factor of 0.95 for intertidal sectors. Initial values of the state variables were derived from field measurements of seed mussels. Initial $L$ and DFM were $0.75 \mathrm{~cm}$ and $1.4 .10^{-3} \mathrm{~g}$, respectively.

The final shell length and dry flesh mass were averaged over years for the 584 points, giving an indication of the spatial growth variability. Standard deviations (SD) of these averages were calculated in order to estimate the inter-annual variability of mussel growth over the years in the whole MSMB.

\section{Results}

\subsection{Satellite data}

Seawater temperature fluctuated according to a seasonal pattern between a minimum of $6{ }^{\circ} \mathrm{C}$ in February and a maximum of $20.4{ }^{\circ} \mathrm{C}$ in August (Figure 2). The annual mean was of $13.10^{\circ} \mathrm{C}$ with an intra-annual standard deviation (SD) of $4.01{ }^{\circ} \mathrm{C}$ corresponding to a coefficient of variation (CV $=$ standard deviation / average) of $30.61 \%$ and an inter-annual SD of $0.26{ }^{\circ} \mathrm{C}(\mathrm{CV}=1.98 \%)$. Only slight differences were observed among sites within the whole area, with a mean SD of $0.17{ }^{\circ} \mathrm{C}$ corresponding to a CV of $1.27 \%$.

Chl-a generally exhibited a seasonal pattern, with maximum values in spring and minimum values in late autumn and winter (Figure 2). The annual Chl-a concentration from 1998 to 2007 averaged $1.45 \mu \mathrm{g} \mathrm{L}^{-1}$ with an intra-annual SD of $1.15 \mu \mathrm{g} \mathrm{L}^{-1}(\mathrm{CV}=79.3 \%)$ and an inter-annual SD of $0.32 \mu \mathrm{g}$ $\mathrm{L}^{-1}(\mathrm{CV}=22.07 \%)$. The magnitude and timing of blooms appeared quite different among years. For example, the spring bloom reached $20 \mathrm{\mu g} \mathrm{L}^{-1}$ of Chl-a in 2001 in contrast to $2.5 \mu_{\mathrm{g} \mathrm{L}}^{-1}$ in 2005. Figure 3 shows an example of data extracted from satellite images for May and December 2003. A positive geographical gradient could be observed from west to east in the bay with maximum values in the southeast part of the bay, close to the location E. The overall spatial SD averaged $0.54 \mu \mathrm{g} \mathrm{L}^{-1}$ corresponding to a mean $\mathrm{CV}$ of $37.6 \%$. This spatial distribution in Chl-a concentration may be clearly observed from May to September during the most productive period for primary production (i.e. highest Chl-a concentrations). For the rest of the year, there was no particular gradient. In winter, the measured concentrations revealed a strong homogeneity among locations.

\subsection{Calibration step and model performance}

The calibration step that was performed on the 23 growth profiles gave a $X_{K}$ value of $1.61 \mu \mathrm{g} \mathrm{L}^{-1}$ and a shape coefficient $\left(\delta_{V}\right)$ value of 0.274 . These values were used in all our simulations.

The observed mussel growth for both culture methods, i.e. bag and pole surveys, was correctly simulated by the model, both in shell length and dry flesh mass (DFM) (Figure 4, 5), without any significant difference between observed and simulated growth, i.e. model $Y=X$ (Figure 6, Table 4). Moreover, there was no difference in the mussel growth between the two rearing methods (bags vs poles). Nonetheless, some dispersion among points appeared in the data, mainly for DFM, which may explain the low values of the determination coefficient, i.e. $49 \%$ for bags and $52 \%$ for poles. The simulated growth in shell length $(\mathrm{L})$ exhibited a seasonal pattern with a period of rapid growth during the warm season from March to September, and a period of (almost) null growth during the cold season (Figure 4, 5). Except for 2005, the model overestimated $L$ of $M$. edulis during the first cold season, i.e. before the 15 April, but last part of the growth cycle was well described by the 
model. Spatial and inter-annual variability were also well described by the model. For instance, the year 2003 shows high growth in L and DFM without any marked halt during the cold season. Conversely, the year 2005 exhibited slow growth, during both warm and cold seasons (Figure 4). The spatial gradient was more pronounced for DFM profiles than for $L$ profiles, with the highest growth found in the eastern part of the bay (site E) and the lowest growth in the western part (site A). The inter-annual growth variability implies a difference in the timing of spawning. As a consequence of the low growth in 2005, no spawning occurred during the first year of growth, whereas all the other annual surveys showed two spawning events, one during the first year and the other during the second year of the mussel growth cycle.

\subsection{Large scale application}

The mean final length and dry flesh mass and their corresponding standard deviations were simulated and mapped over the whole bay (0). Both L and DFM showed a clear spatial pattern following a positive gradient from west to east ( $0 a$ and $7 b$ ). Final $L$ and DFM ranged, according to the different sectors, from 2.68 to $4.04 \mathrm{~cm}$ and from 0.22 to $0.72 \mathrm{~g}$, respectively. The highest growth performances were found in the south-eastern part of the bay close to the river exit, and in a small area, east of the Chausey Islands. The lowest mussel growth was found in a small area in the eastern part of Cancale, in the southwest of the bay $(0 a, 7 b)$.

The inter-annual growth variability in L and DFM, expressed by the standard deviation (SD), exhibited specific spatial patterns. The variability in $L$ appears to be independent of the mean, with the largest SD in the centre of the bay and the lowest SD close to the coast (0c). This pattern can be explained by the low variability in mussel length, ranging from 0.11 to $0.26 \mathrm{~cm}$. Conversely, the standard deviation for DFM seems to be related to the mean, with a positive west to east gradient showing a large area of high variability covering the eastern half of the bay (Od). The dry flesh mass SD ranged from 0.05 to $0.1 \mathrm{~g}$. For both $\mathrm{L}$ and DFM, the small area close to the Chausey Islands exhibits the lowest variability while the standardized variation, expressed by the coefficient of variation (CV), shows the same pattern, with low variability close to the coast (0e, 7f). Thus, length and dry flesh mass CV range from 2.8 to $8.3 \%$ and from 8.8 to $26.3 \%$, respectively.

\section{Discussion}

Since Bayne's Scope for Growth paper (Bayne, 1976), numerous studies have been conducted on the energy budget of mussels, Mytilus edulis. Different types of models for energy acquisition and allocation have been proposed for this species (Scholten and Smaal, 1998). In our study, we used the DEB model, which had previously been applied to $M$. edulis by Ross and Nisbet (1990) and by van Haren and Kooijman (1993). Based on a recent version of the DEB-mussel model developed by Rosland et al. (2009), we used satellite-derived environmental data (i.e. temperature and Chl-a) to describe the mussel growth variability in MSMB. To our knowledge, this is the first time that such a forcing has been made. The calibration step made it possible to validate the capability of the DEB model forced with satellite-derived data to describe spatial and temporal variability in mussel growth as observed on the field. As reported by Riera (2007) in a study with isotopic markers in MSMB, there is a prevalence of the phytoplankton in the mussel diet. Our results, using Chl-a as a food marker, seems to confirm this prevalence.

Only two parameters of the model, the half-saturation coefficient $X_{K}$ and the shape coefficient $\delta_{V}$ were calibrated. $\delta_{V}$ defines how surface areas and volumes, which are linked to acquisition and maintenance processes, respectively, are related to one another. We made the choice of recalibrating $\delta_{V}$ due to a systematic under-estimation of mussel DFM when using the value of 0.231 given by Rosland et al. (2009) for Norwegian sites. We obtained 0.274 as a new value of $\delta_{V}$ for $M$. edulis in MSMB, which is closer to the $\delta_{V}$ value of 0.287 estimated by van der Veer et al. (2006). This parameter could then be site-specific, related to environmental parameters like hydrodynamics, density or food level, and possibly linked to rearing practices, e.g. cultivation method, rearing density (Alunno-Bruscia et al., 2001; Seed, 1968).

The value of the half-saturation coefficient $X_{K}$ was $1.61 \mu \mathrm{g} \mathrm{L}^{-1}$, which is higher than the value of $1.29 \mu \mathrm{g} \mathrm{L}^{-1}$ found by Rosland et al. (2009) but still in the range of the confidence interval ( 0.85 to $2.65 \mathrm{~m} \mathrm{~L} \mathrm{~L}^{-1}$ ) provided by these authors. Since $X_{K}$ is likely diet- and environment-specific (Bourlès et al., 2009; Pouvreau et al., 2006; Alunno-Bruscia et al., submitted -this issue), differences between 
sites could be related to differences in the phytoplankton composition. In addition, one of the possible explanations for the difference among half-saturation coefficient values could be the sitespecific silt load, i.e. turbidity (Kooijman, 2006), or other particles rejected as pseudo-faeces. Indeed, compared to the low seston conditions in Norwegian sites, the waters of MSMB present higher phytoplankton concentrations and may contain higher inorganic matter (up to $50 \mathrm{mg} \mathrm{L}^{-1}$, unpublished data) due to the large inter-tidal area influenced by a strong tidal regime. Inorganic seston may be deleterious for suspension-feeding species (Kooijman, 2006; Ren, 2009). Incorporating inorganic matter into the functional response could, therefore, be a potentially useful way of improving our predictions and making it possible to apply the same parameterisation in different locations (Ren, 2009). Since satellite-derived data supply particulate inorganic matter (PIM) concentration the introduction of PIM concentration in the functional response may be an interesting prospect of this study. Nonetheless, it is noteworthy that a single value of $X_{K}$ allowed a good fit of the simulations against observations over a heterogeneous water body of 1000 ha and for 4 successive years.

Despite the capacity of the satellite-Chl-a signal to explain a large proportion of the mussel growth, the half saturation coefficient does not integrate the temporal variability in the food quality. This could explain some of the differences observed between our simulations and the observations. Energy uptake during spring and summer was under-estimated and, inversely, the energy uptake in autumn and winter was over-estimated (Figure 4, 5). In coastal ecosystems, phytoplankton composition exhibits a clear diversity, showing a seasonal signal with species succession (Gailhard et al., 2002; Pannard et al., 2008). Some of the species contributing to the fluorescence signal could present morphological characteristics (e.g. size, shape) or toxicity deleterious to mussel ingestion and/or assimilation. Moreover, the carbon (C) to Chl-a ratio clearly shows that seasonal variability depends on nutrients, temperature and light (Cloern et al., 1995; Pridmore and Hewitt, 1984). The amount of energy contained in the same quantity of fluorescence could, therefore, be variable (minimum in winter, maximum in summer). In a recent study on modelling the growth of Crassostrea giga, the use of a variable rather than fixed $\mathrm{Chl}-\mathrm{a}: \mathrm{C}$ ratio allowed simulations to be improved (Grangeré et al., 2009). As long as Chl-a is used as a proxy of trophic resources, therefore, integration of a quality index for the seasonal variability of phytoplankton, might improve growth simulations significantly.

In our study, the reproductive cycle of $M$. edulis has been simplified and the spawning events have been partially adjusted through different gonado-somatic index $\mathrm{Gl}$ and temperature threshold $\mathrm{T}_{\mathrm{S}}$. This simplification of the reproductive cycle could partly explain the poor fit between simulated and observed DFM, mainly during the spawning period. In temperate areas, the mussel $M$. edulis is well known to present a sexual cycle clearly alternating between a resting phase during summer, with accumulation of glycogen storage, and a gametogenesis phase over the rest of the year (Lubet, 1956; Lubet, 1959). To improve the prediction of sexual cycle dynamics and the date of spawning, a new state variable giving the dynamics of gamete production and gonad shrinking could be incorporated, as developed for $C$. gigas by Bernard et al. (submitted -this issue). In any case, despite the present lack of precision, our simulations point out the link between the food variability and the reproductive dynamics of $M$. edulis. The first year spawning appears to be highly determined by the amount of food, as simulated in 2005 when no spawning occurred. In the DEB theory, however, the energy allocated to reproduction usually does not affect the structure compartment and the individual length - at least when food supply is large enough to support maintenance costs (Pouvreau et al., 2006). Any improvement of the reproduction mechanisms would likely not modify length predictions. The large-scale application of the model beyond the current rearing area showed both spatial and temporal variability in mussel growth performances. The overall trend appeared strongly linked to the spatio-temporal variability in Chl-a concentration. A gradient of growth from the coast to the outer part of the bay is demonstrated, mainly in the eastern part of the bay. The inter-annual variability in DFM, expressed by the standard deviation, exhibits a spatial pattern highly linked to the mean DFM gradient: the highest absolute variations were recorded close to the coast. However, due to the lowest magnitude of the variability in shell length, the spatial pattern of its inter-annual variability did not follow the mean pattern, and exhibited higher values in the centre of the bay than close to the coast. For both $L$ and DFM, the standardized variation expressed in terms of coefficient of variation shows the same pattern, with the lowest variability close to the coast. The area close to the coast in the eastern part of the bay, therefore, seems to be a sector with good growth that would be suitable for the extension of mussel farming activities. Enrichment by terrestrial nutrients through rivers located in the southeast of the bay may explain the high growth of $M$. edulis in this sector. Conversely, the southwest part of 
the bay showed the lowest mussel growth. This may be explained by the filtration pressure of the cultivated ( $M$. edulis, $C$. gigas and $O$. edulis) and invasive (Crepidula fornicata) mollusc species, concentrated in the western part of the bay (Cugier et al., 2010a). It is clear that Chl-a concentration reflects the actual interactions between primary production and benthic filter-feeders and would change in relation to variability of nutrient inputs, extension of mussel farming and changes in other competitors (Cugier et al., 2010a, Cugier et al., 2010b). We did not examine longterm changes but very recent work showed that temperature and Chl-a exhibit several patterns of inter-annual variability. Regional climate influences coastal European systems and modifies physical and chemical parameters and Chl-a (Goberville et al., 2010). It has been attributed to temperature, local atmospheric and ocean circulation. In the Bay of Biscay (close to the English Channel), the temperature evolution over the past 40 years has been investigated by using field data completed with satellite data (Michel et al., 2009). A strong warming of $0.2^{\circ} \mathrm{C}$ per decade has been found over the period from 1965 to 2004. This trend is not steady, as a cooling period occurred until the early 1970 s, and the temperature increase has been significantly stronger during the last 20 years $\left(0.3^{\circ} \mathrm{C}\right.$ per decade from 1986 to 2005). The inter-annual variability is also very important. Michel et al. (2009) highlighted the potential implications with respect to species distribution and dynamics of species exploited by fisheries. These effects remain to be assessed, and DEB models are likely to be used in a near future to assess the response of biological traits to environmental changes (Kearney et al., 2010). Again, the combination of DEB models and satellite images offers an excellent opportunity to investigate long term ecosystem changes.

Understanding and predicting spatial structures and marine ecosystem dynamics in relation to environmental variability require complementary tools combining models and observations at different scales. This also stands for carrying capacity assessment, and it has been acknowledged that no single tool would address all dimensions of carrying capacity in the frame of Ecosystem Approach to Aquaculture (EAA). The integration of several levels of organisation, e.g. individual, population and ecosystem (Beadman et al., 2002) is a major stake in the EAA (Soto et al., 2008). In a recent paper Nunes et al. (2011) illustrate how assessment tools associated in a multi-method evaluation framework address different scales. At ecosystem scale, the coupling between different types of models (DEB, ecosystem, etc.) has already been successfully implemented to assess the interactions between cultivated species and ecosystem dynamics (Grangeré et al., 2010; Guyondet et al., 2010; Duarte et al., 2003; Cugier et al., 2010a). Our approach lies in between system and local scales issues, since we screen spatial variability of potential mussel growth over a whole ecosystem. The information provided by our model can help local farmers to select sites according to an indicator of potential growth. We suggest that a quantitative indicator of mussel growth improves suitability indices resulting from a combination of several types of information commonly used in the building of suitability indicators. With respect to environmental constraints, Radiarta et al. (2008) only consider qualitative information, e.g. minimum and maximum temperature, salinity and chlorophyll ranges. Ecophysiological models clearly show that, within such suitability domains, a large variation of individual growth is expected. However, it must be kept in mind that this extrapolated growth assumes low densities of mussels. Indeed, this approach neglects the depletion of food density that necessarily results from the establishment of high stock levels, as reported by Cugier et al. (2010a) for the western part of MSMB. A straightforward development would take into account local density effects through the so-called depletion models (Bacher et al., 2003) or farm-scaled models (Nunes et al., 2011). Such models require input data which come from discrete sampling (Bacher et al., 2003) or ecosystem models (Nunes et al., 2011). Alternatively, the use of satellite images will allow to replace scarce input data (temperature, Chl-a) by datasets continuous over time and space. We therefore intend to provide farmers with additional information on suitable density (with respect to farm scale production and environment impact). It would exactly follow the computing steps described by Bacher et al. (2003). Our model may therefore be considered as a suitable method to account for environmental impacts (food and temperature variations) on the response (growth and reproduction) of an organism subject to varying environmental conditions. Such biological responses may also be included in a Geographical Information System describing the potential uses of a coastal area (Kapetsky and Aguilar-Manjarrez, 2007; Radiarta et al., 2008; Salam et al., 2003) and, thus, contribute to spatial planning of coastal ecosystems by addressing three issues: suitability of sites for aquaculture, extension of the aquaculture area, and response of ecosystems to aquaculture. 
The use of ocean-colour radiometry (OCR) is an appealing option for several reasons - spatial coverage, accuracy of the Ch-a estimation, temporal scales, availability on internet servers. OCR data supply precious information on spatial and temporal variability of environmental parameters, i.e. surface temperature, Chl-a and PIM concentration, surface height and waves, ice cover and (soon) surface salinity. Thanks to the spatial coverage and timeframe of satellite images, it is possible to assess long term variability at a spatial resolution which is consistent with ecological issues - e.g. spatio-temporal variability of phytoplankton in relation with primary production, classification of ecosystem types, detection of harmful algae blooms, assessment of ecosystem changes, indicators of ecosystem health and response to environmental drivers and anthropogenic pressures. IOCCG $(2008,2009 b)$ has published very complete reports on operational uses of OCR in marine areas. The value of satellite data for the management of marine resources has become obvious and is emphasized in a number of recent publications (Aguilar-Manjarrez et al., 2010; IOCCG, 2009a). In our paper we described how the combination of remote sensing and modelling provides a map of biological traits for one species in the context of carrying capacity. The results rely upon very few assumptions and give robust and sensible indicators of mussel growth in various places, which makes the approach very attractive for a wide range of issues, e.g. carrying capacity assessment, responses of biological traits to long term environmental changes, assessment of trophic limitations for filter-feeders. Our work relates to interesting and powerful future analyses and developments along two directions. First, the coupling of DEB and farm models (Rosland et al., accepted -this issue) will be implemented using OCR data as input data (temperature, Chl-a) and will allow to predict local mussel production. Second, the combination of OCR data and DEB models for several documented species can be used to investigate the effect of long term environmental changes on biological traits at regional scales (e.g. the English Channel), with reference to the framework described by Kearney et al. (2010) who aim at linking bioenergetics and niche ecology in order to explain habitat structure and ecosystem functions.

\section{Acknowledgments}

This study was supported by the "Programme National Environnement Côtier" (PNEC) and the AquaDEB network (http://www.ifremer.fr/aquadeb/). The authors would like to express their gratitude to the mussel producers and to the regional shellfish association (SRC) for their efficient help and support. The authors also thank I. Bernard and J.-Y. Stanisière for their efficient help in the development of MatLab® code and for the satellite data extraction, and H. McCombie for her helpful comments and English revision.

\section{References}

Aguilar-Manjarrez, J., Kapetsky, J. M., Soto, D., 2010. The potential of spatial planning tools to support the ecosystem approach to aquaculture. FAO/Rome. Expert Workshop. 19-21 November 2008, Rome, Italy. FAO Fisheries and Aquaculture Proceedings. No.17. Rome, FAO., 176p.

Alunno-Bruscia, M., Bourget, E., Frechette, M., 2001. Shell allometry and length-mass-density relationship for Mytilus edulis in an experimental food-regulated situation. Mar. Ecol. Prog. Ser. 219, 177-188.

Alunno-Bruscia, M. Bourlès, Y., Maurer, D., Robert, S., Mazurié, J., Gangnery, A., Goulletquer, P., Pouvreau, S. Submitted. A single bioenergetics growth and reproduction model for the oyster Crassostrea gigas in six Atlantic ecosystems. J. Sea Res. -this issue.

Bacher C., Grant J., Hawkins A., Fang J., Zhu M., Besnard M., 2003. Modelling the effect of food depletion on scallop growth in Sungo Bay (China). Aquatic Living Resources, 16, 10-24.

Bacher, C., Gangnery, A., 2006. Use of dynamic energy budget and individual based models to simulate the dynamics of cultivated oyster populations. J. Sea Res. 56, 140-155. 
Bacher, C., Héral, M., Deslous-Paoli, J. M., Razet, D., 1991. Modèle énergétique uni-boîte de la croissance des huîtres (Crassostrea gigas) dans le bassin de Marennes-Oléron. Can. J. Fish. Aquat. Sci. 48, 391-404.

Baird, R. H., 1966. Factors affecting the growth and condition of mussels (Mytilus edulis L), fishery investigation. Ministry of Agriculture, Fisheries and Food, London, Ser. II 25, 1-33.

Barillé, L., Héral, M., Barillé-Boyer, A. L., 1997. Modélisation de l'écophysiologie de l'huître Crassostrea gigas dans un environnement estuarien. Aquat. Living Resour. 10, 31-48.

Bayne, B. L., 1976. Marine Mussels: Their Ecology and Physiology. Cambridge University Press, Cambridge, $506 \mathrm{pp}$.

Beadman, H. A., Willows, R. I., Kaiser, M. J., 2002. Potential applications of mussel modelling. Helg. Mar. Res. 56, 76-85.

Bernard, I., De Kermoysan, G., Pouvreau, S. Submitted. Effect of phytoplankton and temperature on the reproduction of the Pacific oyster Crassostrea gigas: investigation through DEB theory. J. Sea Res. -this issue.

Bourlès, Y., Alunno-Bruscia, M., Pouvreau, S., Tollu, G., Leguay, D., Arnaud, C., Goulletquer, P., Kooijman, S. A. L. M., 2009. Modelling growth and reproduction of the Pacific oyster Crassostrea gigas: Advances in the oyster-DEB model through application to a coastal pond. J. Sea Res. 62, 62-71.

Cardoso, J., Witte, J. I., van der Veer, H. W., 2006. Intra- and interspecies comparison of energy flow in bivalve species in Dutch coastal waters by means of the Dynamic Energy Budget (DEB) theory. J. Sea Res. 56, 182-197.

Casas, S., Bacher, C., 2006. Modelling trace metal $(\mathrm{Hg}$ and $\mathrm{Pb})$ bioaccumulation in the Mediterranean mussel, Mytilus galloprovincialis, applied to environmental monitoring. J. Sea Res. 56, 168-181.

Cloern, J. E., Grenz, C., Vidergar-Lucas, L., 1995. An empirical model of the phytoplankton chlorophyll: carbon ration - the conversion factor between productivity and growth rate. Limnol. Oceanogr. 40, 1313-1321.

Cugier, P., Struski, C., Blanchard, M., Mazurié, J., Pouvreau, S., Olivier, F., Trigui, J. R., Thiébaut, E., 2010a. Assessing the role of benthic filter feeders on phytoplankton production in a shellfish farming site: Mont Saint Michel Bay, France. J. Marine Syst. 82, 21-34.

Cugier P., Frangoudes K., Blanchard M., Mongruel R., Perez J., Le Mao P., Robin T., Fontenelle G., Mazurie J., Cayocca F., Pouvreau S., Olivier F., 2010b. Impact des facteurs environnementaux et des pratiques conchylicoles sur la baie du Mont Saint-Michel et la production conchylicole. Etude de scenarii par modélisation. Programme Liteau 3. Rapport Final. http://archimer.ifremer.fr/doc/00026/13707/

Douvere, F., Ehler, C. N., 2009. New perspectives on sea use management: Initial findings from European experience with marine spatial planning. J. Environ. Manage. 90, 77-88.

Dowd, M., 2005. A bio-physical coastal ecosystem model for assessing environmental effects of marine bivalve aquaculture. Ecol. Model. 183, 323-346.

Duarte, P., Meneses, R., Hawkins, A. J. S., Zhu, M., Fang, J., Grant, J., 2003. Mathematical modelling to assess the carrying capacity for multi-species culture within coastal waters. Ecol. Model. 168, 109-143.

Gailhard, I., Gros, P., Durbec, J. P., Beliaeff, B., Belin, C., Nezan, E., Lassus, P., 2002. Variability patterns of microphytoplankton communities along the French coasts. Mar. Ecol. Prog. Ser. 242, 39-50.

Goberville, E., Beaugrand, G., Sautour, B., Treguer, P., Team, S., 2010. Climate-driven changes in coastal marine systems of western Europe. Mar. Ecol. Prog. Ser. 208, 129-147.

Gohin, F., Druon, J. N., Lampert, L., 2002. A five channel chlorophyll concentration algorithm applied to SeaWiFS data processed by SeaDAS in coastal waters. Internat. J. Remote Sensing 23, 1639 - 1661.

Gohin, F., Lampert, L., Guillaud, J. F. O., Herbland, A., Nezan, E., 2003. Satellite and in situ observations of a late winter phytoplankton bloom, in the northern Bay of Biscay. Cont. Shelf Res. 23, 1117-1141.

Gohin, F., Saulquin, B., Oger-Jeanneret, H., Lozac'h, L., Lampert, L., Lefebvre, A., Riou, P., Bruchon, F., 2008. Towards a better assessment of the ecological status of coastal waters using satellite-derived chlorophyll-a concentrations. Remote Sensing Envir. 112, 3329-3340.

Grangeré, K., Lefebvre, S., Bacher, C., Cugier, P., Ménesguen, A., 2010. Modelling the spatial heterogeneity of ecological processes in an intertidal estuarine bay: dynamic interactions between bivalves and phytoplankton. Mar. Ecol. Prog. Ser. 415, 141-158. 
Grangeré, K., Ménesguen, A., Lefebvre, S., Bacher, C., Pouvreau, S., 2009. Modelling the influence of environmental factors on the physiological status of the Pacific oyster Crassostrea gigas in an estuarine embayment; The Baie des Veys (France). J Sea Res. 62, 147-158.

Grant, J., Bacher, C., 1998. Comparative models of mussel bioenergetics and their validation at field culture sites. J. Exp. Mar. Biol. Ecol. 219, 21-44.

Guyondet, T., Roy, S., Koutitonsky, V.G., Grant, J., Tita, G., 2010. Integrating multiple spatial scales in the carrying capacity assessment of a coastal ecosystem for bivalve aquaculture. J. Sea Res. 64, 341-359.

Halpern, B. S., Walbridge, S., Selkoe, K. A., Kappel, C. V., Micheli, F., D'Agrosa, C., Bruno, J. F., Casey, K. S., Ebert, C., Fox, H. E. et al., 2008. A global map of human impact on marine ecosystems. Science 319, 948-952.

Heim, B., Oberhaensli, H., Fietz, S., Kaufmann, H., 2005. Variation in Lake Baikal's phytoplankton distribution and fluvial input assessed by SeaWiFS satellite data. Global Planet. Change 46, 927.

Huret, M., Gohin, F., Delmas, D., Lunven, M., Garçon, V., 2007. Use of SeaWiFS data for light availability and parameter estimation of a phytoplankton production model of the Bay of Biscay. J. Mar. Syst. 65, 509-531.

IOCCG, 2008. Why Ocean Colour? The Societal Benefits of Ocean-Colour Technology. Platt, T., Hoepffner, N., Stuart, V. and Brown, C. (eds.), Reports of the International Ocean-Colour Coordinating Group, No. 7, IOCCG, Dartmouth, Canada.

IOCCG. 2009a. Remote sensing in fisheries and aquaculture. Forget, M.-H., Stuart, V. and Platt, T., (eds.), Reports of the international Ocean-Colour Coordinating Group, No. 8, IOCCG, Dartmouth, Canada.

IOCCG, 2009b. Partition of the Ocean into Ecological Provinces: Role of Ocean-Colour Radiometry. Dowell, M. and Platt, T. (eds.), Reports of the International Ocean-Colour Coordinating Group, No. 9, IOCCG, Dartmouth, Canada.

Jiang, W. M., Gibbs, M. T., 2005. Predicting the carrying capacity of bivalve shellfish culture using a steady, linear food web model. Aquaculture 244, 171-185.

Kapetsky, J. M., Aguilar-Manjarrez, J., 2007. Geographic information systems, remote sensing and mapping for the development and management of marine aquaculture. FAO Fisheries Technical Paper No. 458. Rome, FAO, 125 pp.

Kearney M., Simpson S., Raubenheimer D., Helmuth B., 2010. Modelling the ecological niche from functional traits. Phil. Trans. R. Soc. B 12, 365, 3469-3483, doi:10.1098/rstb.2010.0034

Kooijman, S., 1986. Energy budget can explain body size relations. J. Theor. Biol. 121, 269-282.

Kooijman, S., 2006. Pseudo-faeces production in bivalves. J. Sea Res. 56, 103-106.

Kooijman, S. A. L. M., 2010. Dynamic Energy Budget Theory for Metabolic Organisation. Cambridge University Press, 3rd edition, $514 \mathrm{pp}$.

Lubet, P., 1956. Cycle sexuel de Mytilus edulis L. et de Mytilus galloprovincialis Lmk. dans le bassin d'Arcachon (Gironde). Colloque internationa de biologie marine. Annales de Biologie 33.

Lubet, P., 1959. Recherche sur le cycle sexuel et l'émission des gamètes ches les Mytilidés et les Pectinidés (mollusques bivalves). Revue des Travaux de l'Institue des Pêches Maritimes 23.

Mazurié, J., Bouget, J. F., Thomas, Y., 2005. Croissance et production mytilicole en Baie du Mont Saint-Michel, après restructuration : compte-rendu final de l'étude sur 15 pieux entre avril 2004 et janvier 2005. Rapport interne Ifremer RST/LER-MPL/05-10 Septembre 2005 (https://w3.ifremer.fr/archimer/).

McKindsey, C. W., Thetmeyer, H., Landry, T., Silvert, W., 2006. Review of recent carrying capacity models for bivalve culture and recommendations for research and management. Aquaculture 261, 451-462.

Michel S., Vandermeirsch F., Lorance P., 2009. Evolution of upper layer temperature in the Bay of Biscay during the last 40 years. Aquat. Living Resour. 22, 447-461.

Nunes, J.P., Ferreira J.G., Bricker S.B., O'Loan B., Dabrowski T., Dallaghan B., Hawkins A.J.S., O'Connor B., O'Carroll T., 2011. Towards an ecosystem approach to aquaculture: Assessment of sustainable shellfish cultivation at different scales of space, time and complexity. Aquaculture, doi:10.1016/j.aquaculture.2011.02.048.

O'Reilly, J. E., Maritorena, S., Mitchell, B. G., Siegel, D. A., Carder, K. L., Garver, S. A., Kahru, M., McClain, C., 1998. Ocean color chlorophyll algorithms for SeaWiFS. J. Geophys. Res. 103, 24937-24953. 
Pannard, A., Claquin, P., Klein, C., Le Roy, B., Veron, B., 2008. Short-term variability of the phytoplankton community in coastal ecosystem in response to physical and chemical conditions' changes. Estu. Coast. Shelf Sci. 80, 212-224.

Pouvreau, S., Bourlès, Y., Lefebvre, S., Gangnery, A., Alunno-Bruscia, M., 2006. Application of a dynamic energy budget model to the Pacific oyster, Crassostrea gigas, reared under various environmental conditions. J. Sea Res. 56, 156-167.

Pridmore, R. D., Hewitt, J. E., 1984. Chlorophyll a as an indicator of phytoplankton cell volum in 12 lakes, North-Island, New-Zeland. New Zeal. J. Bot. 22, 295-301.

Radiarta, I. N., Saitoh, S. I., Miyazono, A., 2008. GIS-based multi-criteria evaluation models for identifying suitable sites for Japanese scallop (Mizuhopecten yessoensis) aquaculture in Funka Bay, southwestern Hokkaido, Japan. Aquaculture 284, 127-135.

Ren, J. S., 2009. Effect of food quality on energy uptake. J. Sea Res. 62, 72-74.

Ren, J. S., Ross, A. H., 2005. Environmental influence on mussel growth: A dynamic energy budget model and its application to the greenshell mussel Perna canaliculus. Ecol. Model. 189, 347-362.

Rico-Villa, B., Bernard, I., Robert, R., Pouvreau, S., 2010. A Dynamic Energy Budget (DEB) growth model for Pacific oyster larvae, Crassostrea gigas. Aquaculture 305, 84-94.

Riera, P., 2007. Trophic subsidies of Crassostrea gigas, Mytilus edulis and Crepidula fornicata in the Bay of Mont Saint Michel (France): A $\delta 13 \mathrm{C}$ and $\delta 15 \mathrm{~N}$ investigation. Estuar. Coast. Shelf S. 72, 33-41.

Rivas, A. L., Dogliotti, A. I., Gagliardini, D. A., 2006. Seasonal variability in satellite-measured surface chlorophyll in the Patagonian Shelf. Cont. Shelf Res. 26, 703-720.

Rosland, R., Strand, Ø., Alunno-Bruscia, M., Bacher, C., Strohmeier, T., 2009. Applying Dynamic Energy Budget (DEB) theory to simulate growth and bio-energetics of blue mussels under low seston conditions. J Sea Res. 62, 49-61.

Rosland R., Bacher C., Strand $\varnothing$. ., Aure J., Strohmeier T., Accepted. Modelling growth variability in longline mussel farms as a function of stocking density and farm design. J. Sea Res. -This issue.

Ross, A. H., Nisbet, R. M., 1990. Dynamic models of growth and reproduction of the mussel Mytilus edulis L. Funct. Ecol. 4, 777-787.

Salam, M. A., Ross, L. G., Beveridge, C. M. M., 2003. A comparison of development opportunities for crab and shrimp aquaculture in southwestern Bangladesh, using GIS modelling. Aquaculture 220, 477-494.

Sara, G., Mazzola, A., 2004. The carrying capacity for Mediterranean bivalve suspension feeders: evidence from analysis of food availability and hydrodynamics and their integration into a local model. Ecol. Model. 179, 281-296.

Saulquin, B., Gohin, F., Garrello, R., 2010. Regional objective analysis for merging high resolution MERIS, MODIS/Aqua and SeaWiFS Chlorophyll-a data from 1998 to 2008 on the European Atlantic Shelf. IEEE Transaction on Geoscience and Remote Sensing.

Schneider, D. W., 1992. A bioenergetics model of zebra mussel, Dreissena polymospha, growth in the Great-Lakes. Can. J. Fish. Aquat. S. 49, 1406-1416.

Scholten, H., Smaal, A. C., 1998. Responses of Mytilus edulis L. to varying food concentrations: testing EMMY, an ecophysiological model. J. Exp. Mar. Biol. Ecol. 219, 217-239.

Seed, R., 1968. Factors Influencing Shell Shape in the Mussel Mytilus Edulis. J. Mar. Biol. Ass. U.K. 48, 561-584.

Seed, R., 1976. Ecology. In : Bayne, B.L. (Ed.), Marine Mussels : their ecology and physiologie. IBP, vol. 10. Cambridge Univ. Press, Cambridge, pp. 13-65.

Soto, D., Aguilar-Manjarrez, J., Hishamunda, N., 2008. Building an ecosystem approach to aquaculture. FAO Fisheries and Aquaculture Proceedings, No. 14 Rome, 221P.

van der Meer, J., 2006. An introduction to Dynamic Energy Budget (DEB) models with special emphasis on parameter estimation. J. Sea Res. 56, 85-102.

van der Veer, H. W., Cardoso, J., van der Meer, J., 2006. The estimation of DEB parameters for various Northeast Atlantic bivalve species. J. Sea Res. 56, 107-124.

Van Haren, R. J. F., Kooijman, S., 1993. Application of dynamic energy budget model to Mytilus edulis (L.). Neth. J Sea Res. 31, 119-133.

Waite, L., Grant, J., Davidson, J., 2005. Bay-scale spatial growth variation of mussels Mytilus edulis in suspended culture, Prince Edward Island, Canada. Mar. Ecol. Prog. Ser. 297, 157-167. 
Table 1 Summary of the 23 mussel growth surveys made in Mont Saint Michel Bay from 2003 to 2007.

\begin{tabular}{clcll}
\hline Year & Survey & \multicolumn{1}{c}{ Site } & \multicolumn{2}{l}{ Sampling frequency } \\
dates
\end{tabular}

Table 2 Equations describing the energy fluxes in the DEB model. $X$ corresponds to the food concentration ( $\mathrm{Chl} \mathrm{a,} \mathrm{g} \mathrm{I}^{-1}$ ) and $T$ to the water temperature (K). See table 3 for the parameter description.

\begin{tabular}{lll}
\hline $\mathrm{n}^{\circ}$ & Flux description & Equation \\
\hline (1) & Ingestion & $p_{X}=\left\{J_{X m}\right\} \cdot\left(\frac{X}{X+X_{k}}\right) \cdot V^{2 / 3} \cdot f(T)$ \\
(2) & Assimilation & $p_{A}=\kappa_{A}: p_{X}$ \\
(3) & Utilization & $p_{C}=\frac{E / V}{\left[E_{G}\right]+\kappa E / V}\left(\frac{\left[E_{G}\right] \cdot\left\{p_{A m}\right\} \cdot V^{2 / 3}}{\left[E_{m}\right]}+\left[p_{M}\right] \cdot V\right)$ \\
(4) & Somatic growth & $p_{G}=\kappa: p_{C}-p_{M}$ \\
(5) & Somatic maintenance & $p_{M}=\left[p_{M}\right] \cdot V \cdot f(T)$ \\
(6) & Maturation & $p_{R}=(1-\kappa): p_{C}-p_{J}$ \\
(7) & Maturation maintenance & $p_{J}=\min \left(V, V_{p}\right) \cdot\left[p_{M}\right] \cdot\left(\frac{1-\kappa}{\kappa}\right) \cdot f(T)$ \\
(8) & Temperature effect & $f(T)=\exp \left\{\frac{T_{A}}{T_{1}}-\frac{T_{A}}{T}\right\} \cdot\left(1+\exp \left\{\frac{T_{A L}}{T}-\frac{T_{A L}}{T_{L}}\right\}+\exp \left\{\frac{T_{A H}}{T_{H}}-\frac{T_{A H}}{T}\right\}\right)^{-1}$ \\
(9) & $\begin{array}{l}\text { Total dry flesh mass } \\
\text { calculation }\end{array}$ & $D F M=\frac{E+E_{R}}{\mu_{E}}+\left(\frac{E_{V}}{\left[E_{G}\right]} \rho\right) \cdot(1-\omega)$ \\
(10) & $\begin{array}{l}\text { Conversion of } \text { volume (V) into physical } \\
\text { length (L) }\end{array}$ & $L=\frac{V^{1 / 3}}{\delta_{V}} \quad$ with $\quad V=\frac{E_{V}}{\left[E_{G}\right]}$ \\
\hline
\end{tabular}


Table 3 DEB parameters used for Mytilus edulis in this study.

\begin{tabular}{lcccc}
\hline Parameter & Symbol & Unit & Value & Ref. \\
\hline Arrhenius temperature & $\mathrm{T}_{\mathrm{A}}$ & $\mathrm{K}$ & 5800 & $\mathrm{a}$ \\
Max. surf. area-specific ingestion rate & $\left\{p_{x \mathrm{x}}\right\}$ & $\mathrm{J} \mathrm{cm}^{-2} \mathrm{~d}^{-1}$ & 273 & $\mathrm{a}$ \\
Half-saturation coefficient & $\mathrm{X}_{\mathrm{K}}$ & $\mu \mathrm{g}_{\mathrm{Chl}} \mathrm{I}^{-1}$ & 1.61 & $\mathrm{C}$ \\
Assimilation efficiency & $\kappa_{\mathrm{A}}$ & - & 0.75 & $\mathrm{a}$ \\
Volume-specific cost of growth & {$\left[E_{G}\right]$} & $\mathrm{J} \mathrm{cm}^{-3}$ & 1900 & $\mathrm{a}$ \\
Volume-specific cost of maintenance & {$\left[p_{\mathrm{M}}\right]$} & $\mathrm{J} \mathrm{cm}^{-3} \mathrm{~d}^{-1}$ & 24 & $\mathrm{a}$ \\
Maximum energy density & {$\left[E_{m}\right]$} & $\mathrm{J} \mathrm{cm}^{-3}$ & 2190 & $\mathrm{a}$ \\
Structural volume at sexual maturity & $V_{p}$ & $\mathrm{~cm}^{3}$ & 0.06 & $\mathrm{a}$ \\
Fraction of energy used for growth & $\mathrm{K}$ & - & 0.45 & $\mathrm{a}$ \\
Shape coefficient & $\delta_{\mathrm{M}}$ & - & 0.274 & $\mathrm{C}$ \\
Structural volume density & $\rho$ & $\mathrm{g} \mathrm{cm}^{-3}$ & 1 & $\mathrm{~b}$ \\
Water content of the flesh & $\omega$ & $\%$ & 80 & $\mathrm{~b}$ \\
& & & & \\
Lower limit of the tolerance range & $\mathrm{T}_{\mathrm{L}}$ & $\mathrm{K}$ & 275 & $\mathrm{a}$ \\
Upper limit of the tolerance range & $\mathrm{T}_{\mathrm{H}}$ & $\mathrm{K}$ & 296 & $\mathrm{a}$ \\
Arrhenius temperature at the lower limit & $\mathrm{T}_{\mathrm{AL}}$ & $\mathrm{K}$ & 45430 & $\mathrm{a}$ \\
Arrhenius temperature at the upper limit & $\mathrm{T}_{\mathrm{AH}}$ & $\mathrm{K}$ & 31376 & $\mathrm{a}$ \\
Reference temperature & $\mathrm{T}_{1}$ & $\mathrm{~K}$ & 293 & $\mathrm{a}$ \\
Energy content of food & $\mu_{\mathrm{E}}$ & $\mathrm{J} \mathrm{g}^{-1}$ & 17550 & $\mathrm{~b}$ \\
\hline
\end{tabular}

a Rosland et al. (2009), b Pouvreau et al. (2006), c this study

Table 4 Comparison between observed and simulated results for length $(L)$ and dry flesh mass (DFM) of Mytilus edulis for the bag and pole surveys in Mont Saint Michel Bay; coefficient of determination $\left(\mathrm{R}^{2}\right)$, slope of the regression $(a)$ and $p$ value for $a=1\left(p_{\text {slope }}\right)$.

\begin{tabular}{ccccc}
\hline & \multicolumn{2}{c}{ Bags } & \multicolumn{2}{c}{ Poles } \\
Parameter & $\mathrm{L}$ & $\mathrm{DFM}$ & $\mathrm{L}$ & $\mathrm{DFM}$ \\
\hline $\mathrm{R}^{2}$ & 0.84 & 0.49 & 0.64 & 0.52 \\
$\mathrm{a}$ & 0.99 & 0.98 & 0.97 & 1.02 \\
$p_{\text {slope }}$ & $<0.0001$ & $<0.0001$ & $<0.0001$ & $<0.0001$ \\
\hline
\end{tabular}


Figure 1. Geographical position and morphology of Mont-Saint-Michel Bay (MSMB), North Brittany. Identification of the 5 sampling sites (A, B, C, D and E) in the mussel-rearing area.

Figure 2. Water temperature $\left({ }^{\circ} \mathrm{C}\right)$ and chlorophyll-a concentration as measured by NOAA18 and SeaWIFS satellites, respectively, from January 1998 to December 2007. Black lines correspond to the average values calculated over the whole area and grey lines give the corresponding mean + -- standard deviation.

Figure 3. Examples of monthly average chlorophyll-a concentrations $\left(\mu \mathrm{g} \mathrm{L}^{-1}\right)$ in (a) May and (b) December 2003, as extracted from the satellite image at the scale of Mont SaintMichel Bay.

Figure 4. Simulations (lines) and observations (symbols) of the shell length $(\mathrm{cm})$ and dry flesh mass (g) for mussels reared in bags in 2003, 2004, 2005 and 2006 at 5 sites A (•-), B $(\diamond--), C(\triangle \cdots), D(\nabla-)$ and E $(\square--)$ in Mont Saint-Michel Bay. Time begins on 15 March.

Figure 5. Simulations (lines) and observations (symbols) of the shell length $(\mathrm{cm})$ and dry flesh mass (g) for mussels reared on poles in 2004 and 2006 at 5 sites A (•-), B (•---), C $(\Delta \cdots), D(\nabla-)$ and $E(\square--)$. Time begins on 15 March.

Figure 6. Simulations plotted against observations of the shell length $(\mathrm{cm})$ and dry flesh mass (g), for mussels cultivated in bags (open circles) and on poles (black circles), data compiled over all years.

Maps of the final averaged shell length $(\mathrm{cm} ; \mathrm{a})$ and dry flesh mass $(\mathrm{g} ; \mathrm{b})$ simulated by the DEB model. Standard deviations (SD) and coefficient of variation (CV) are given respectively for shell length (SD: $c ; C V: e)$ and dry flesh mass (SD: d; CV: f). 


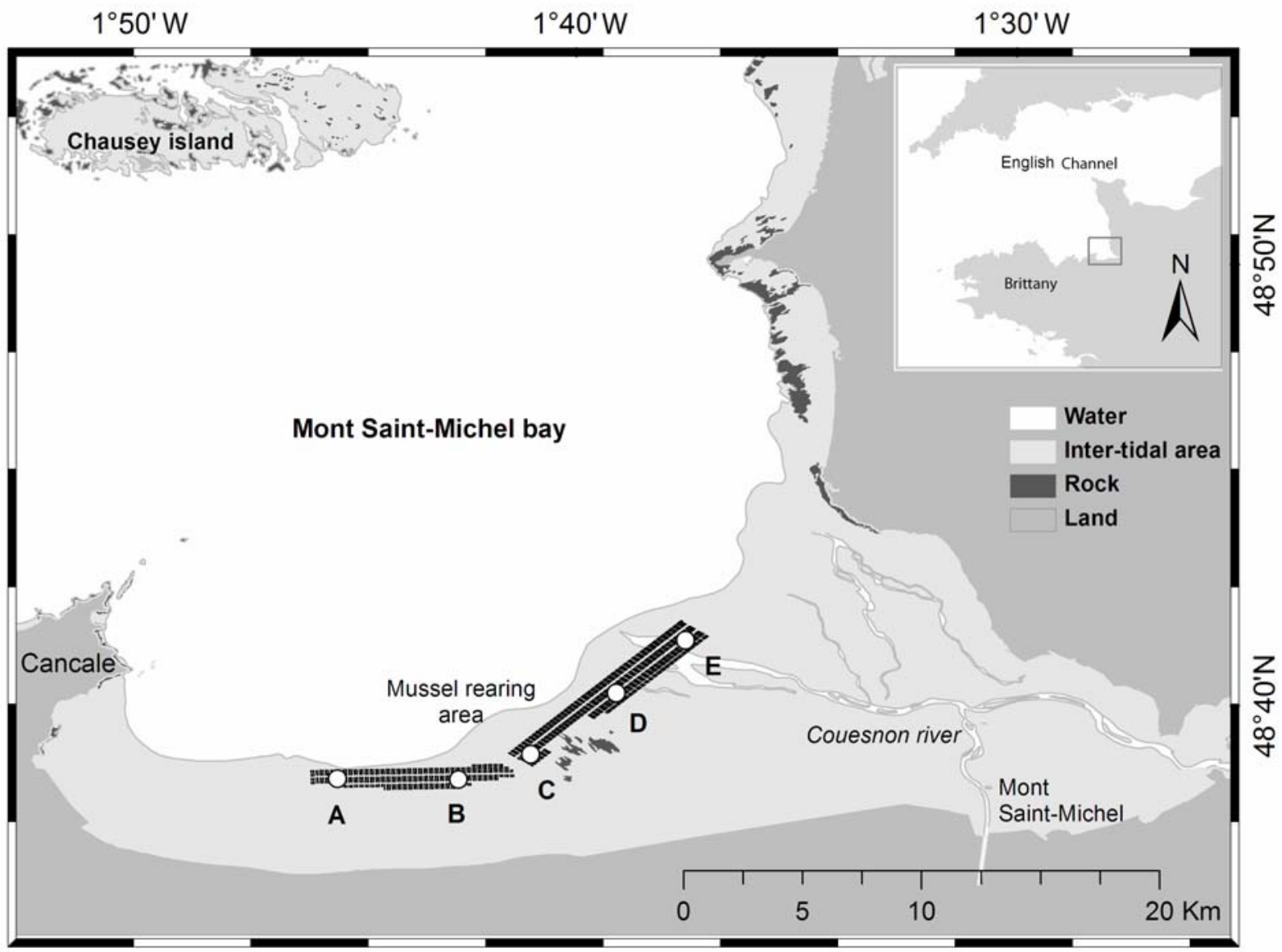

Figure 1 

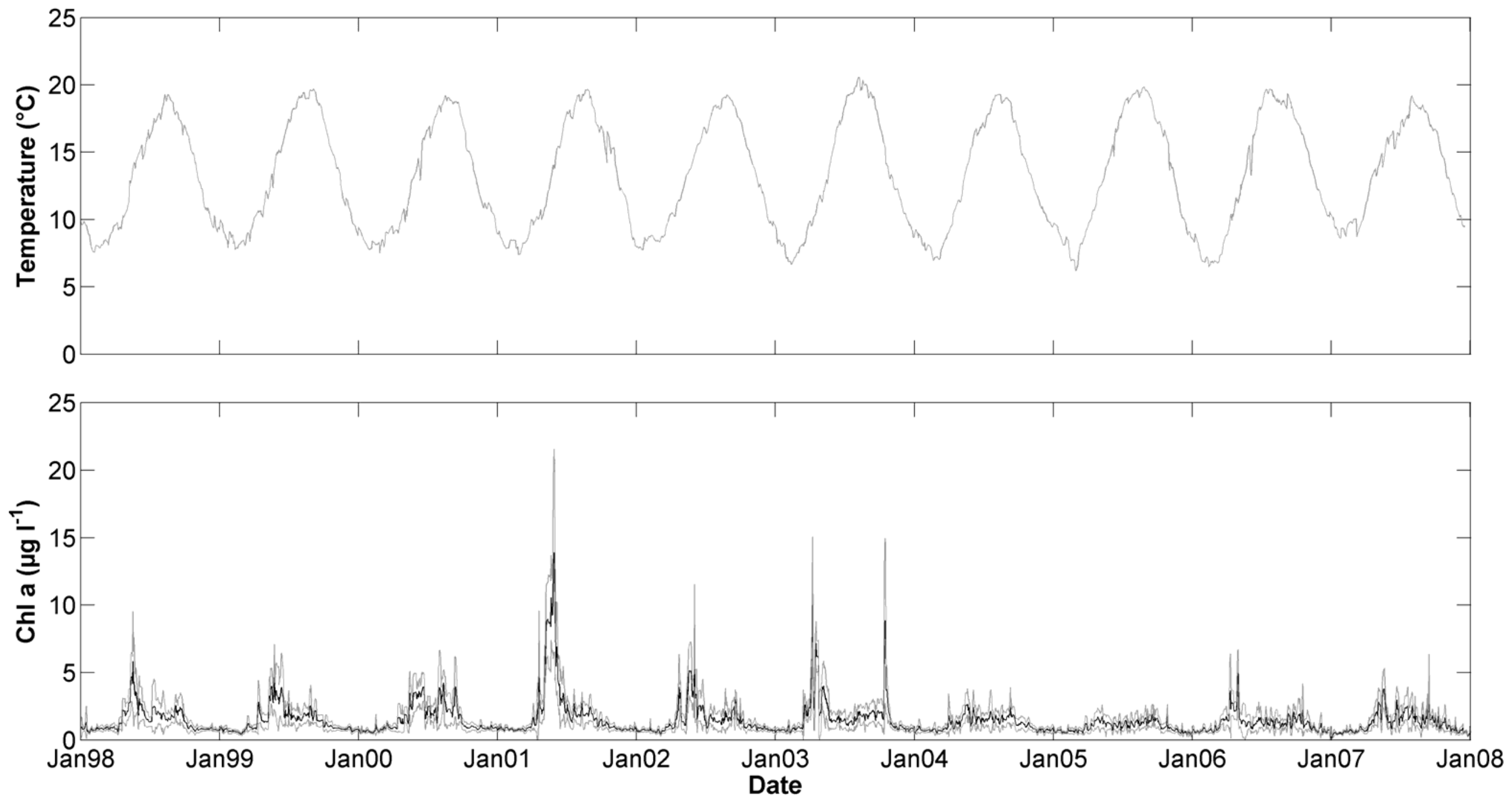

Figure 2 


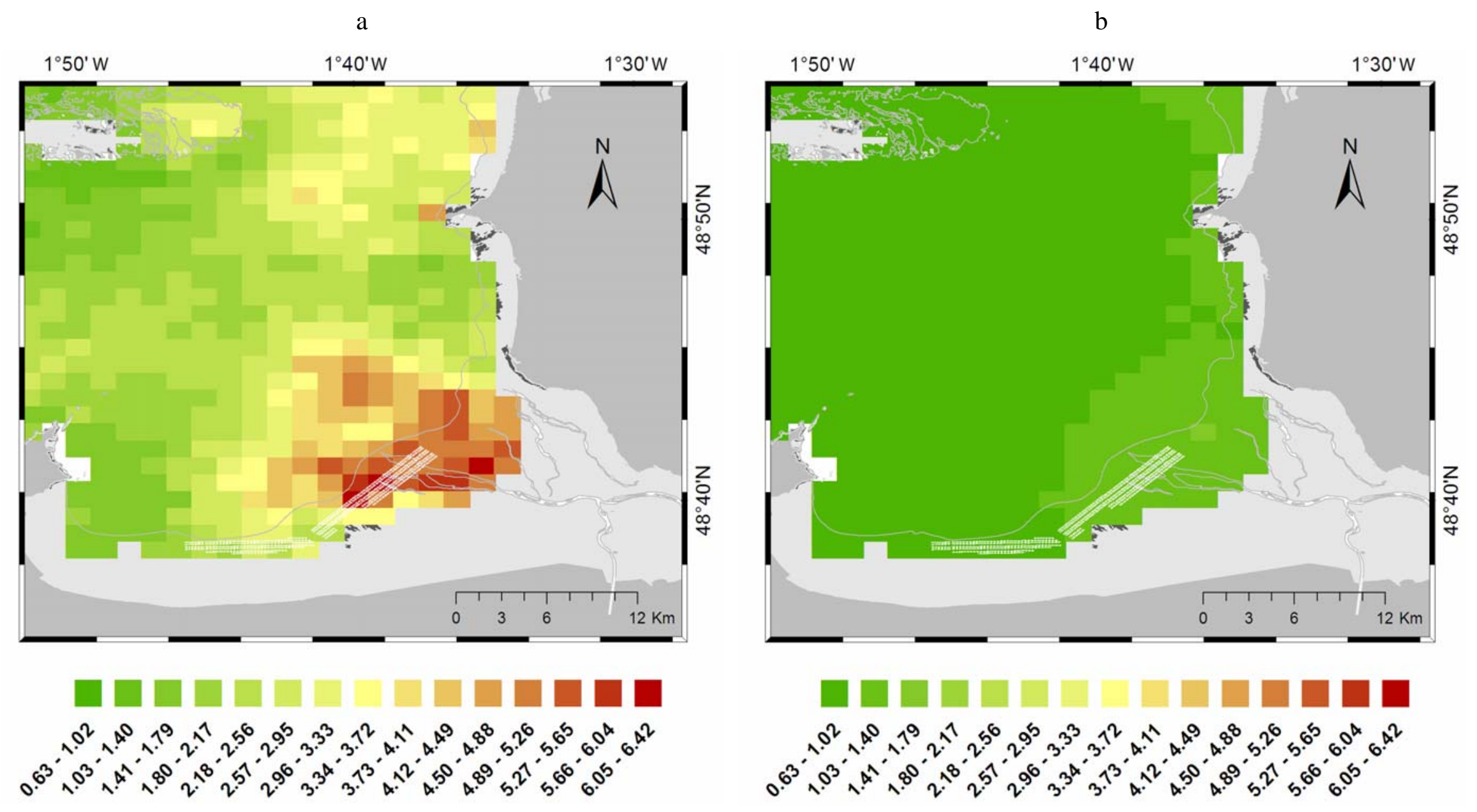

Figure 3 

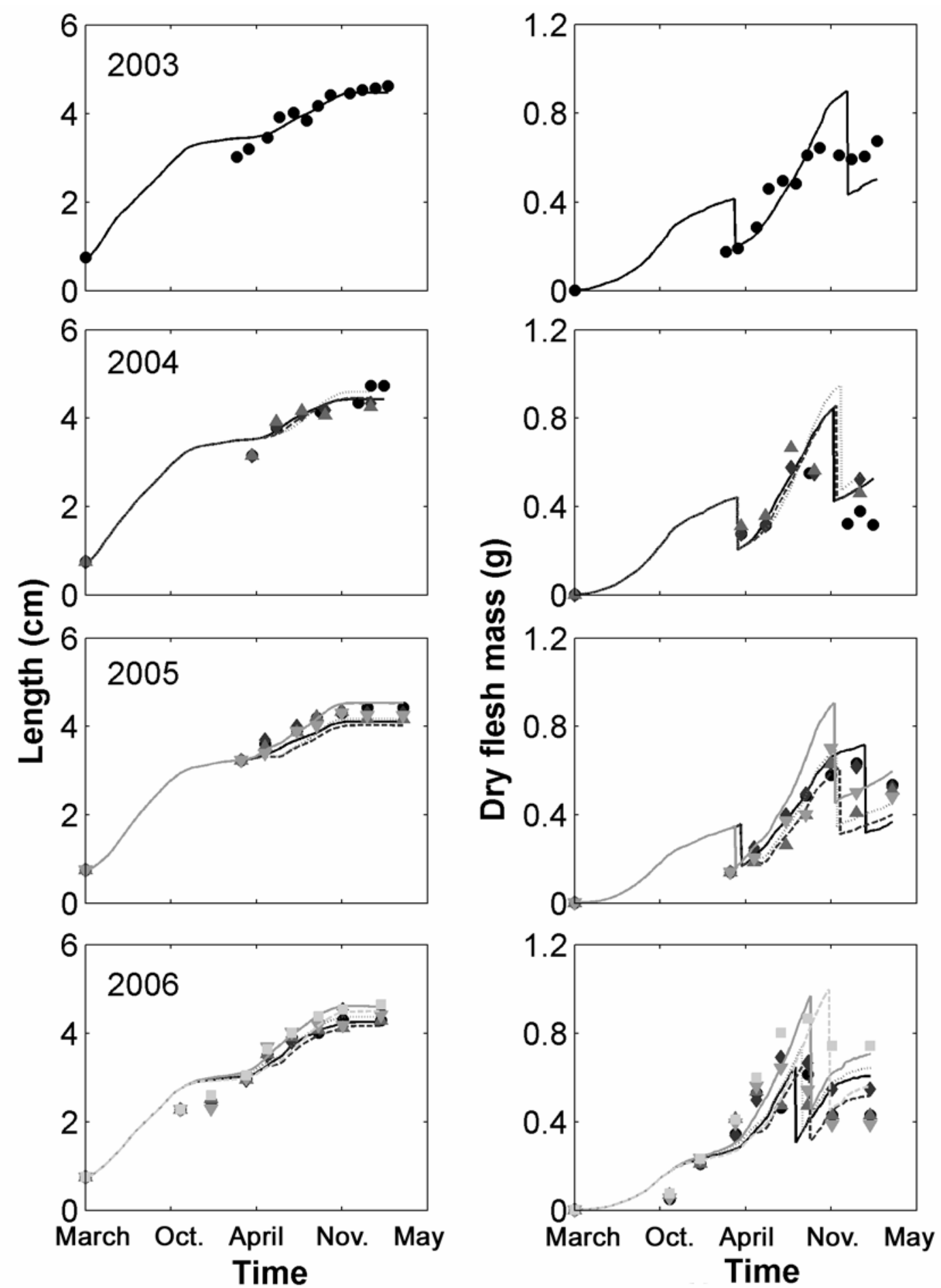

Figure 4 

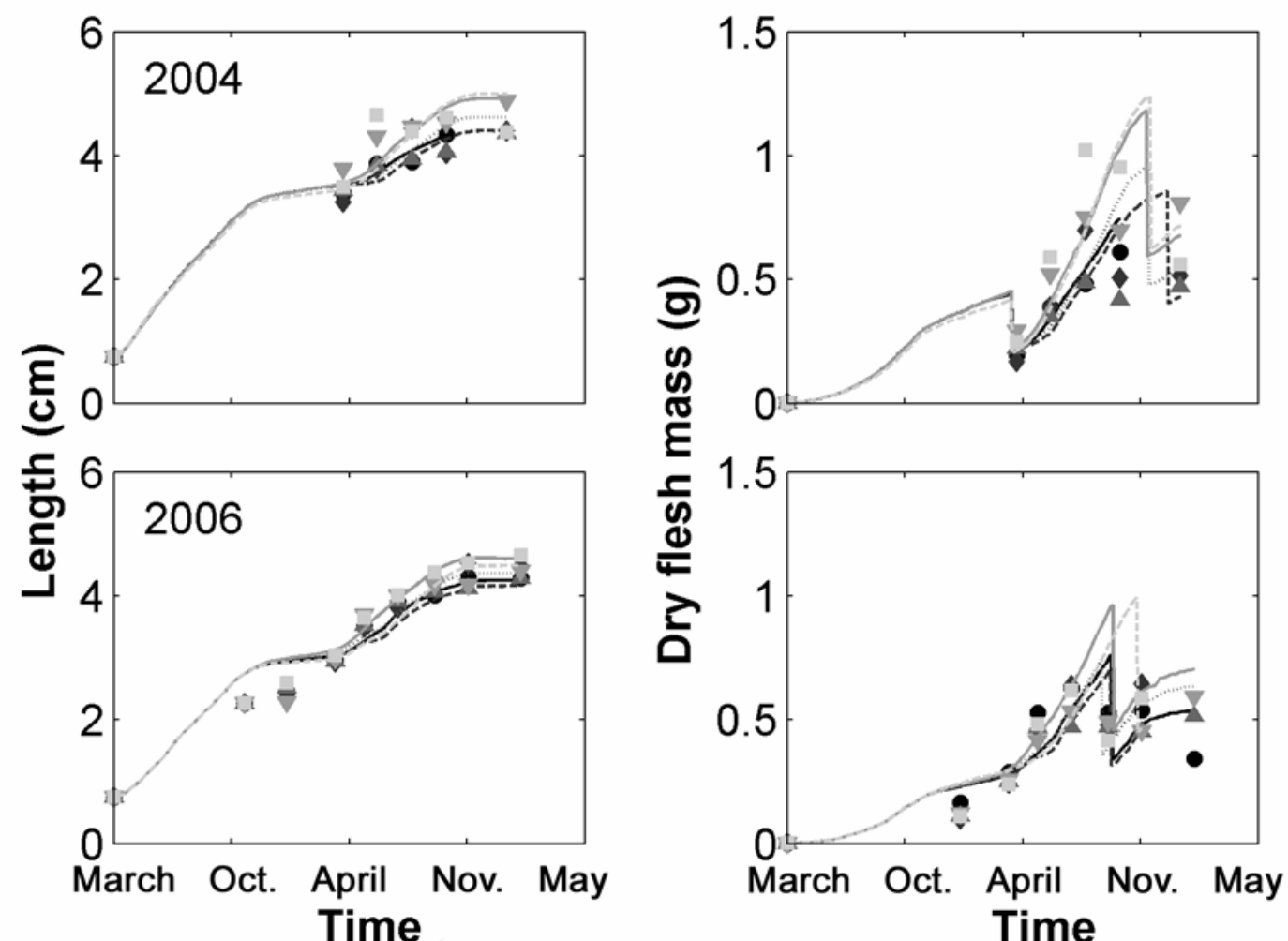

Figure 5 

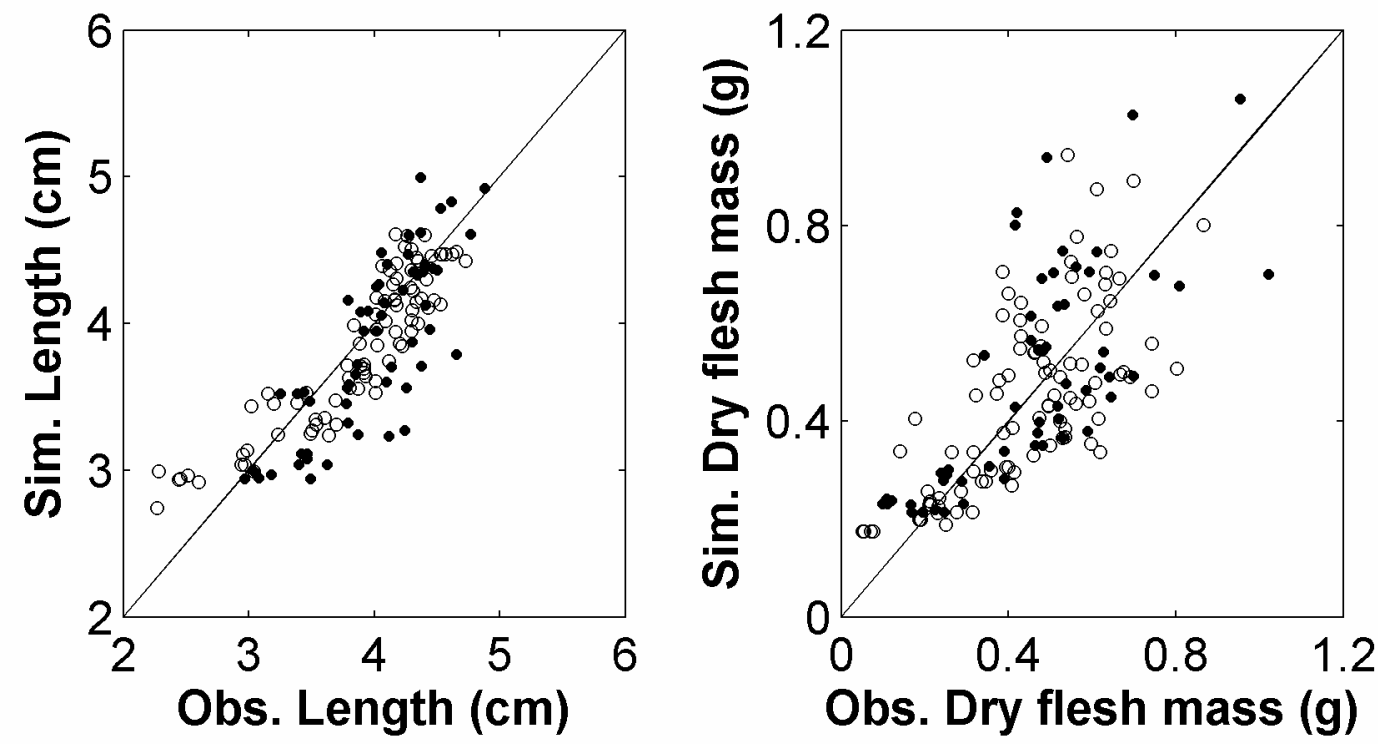

Figure 6 


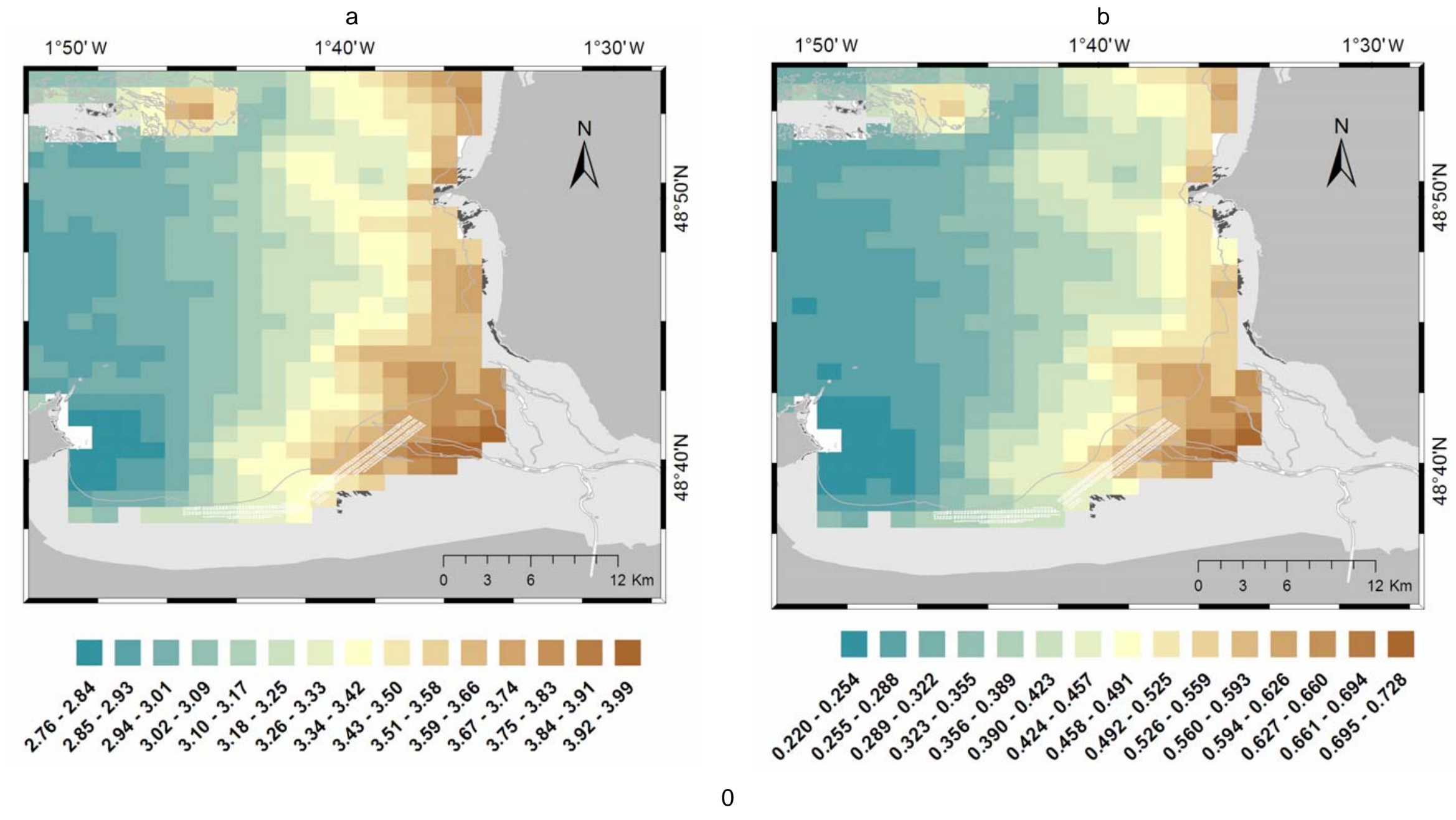




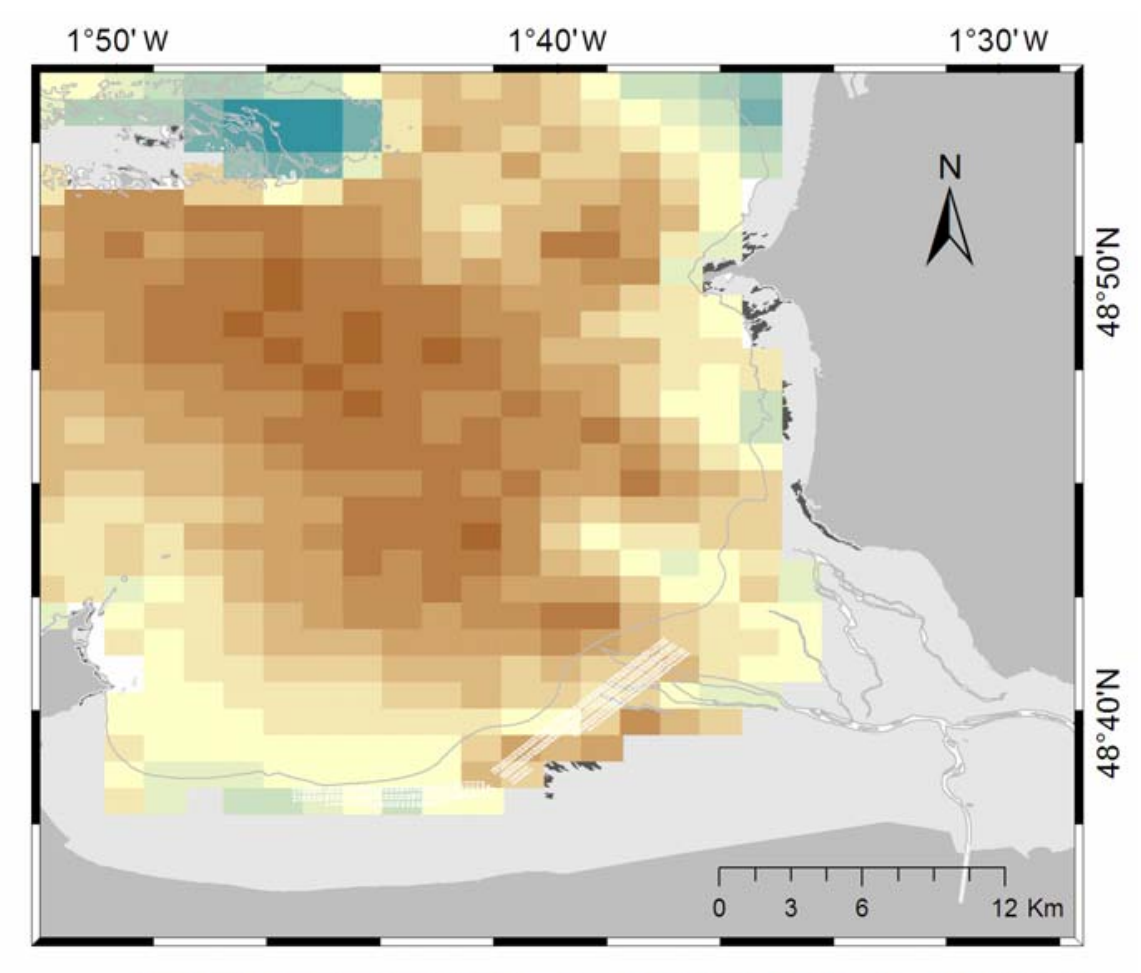

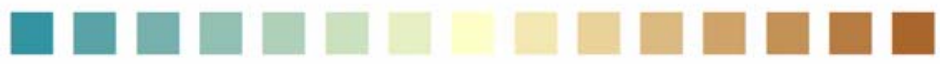

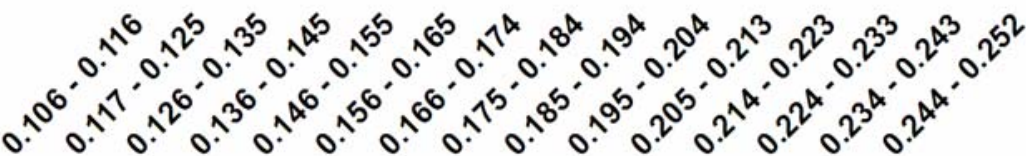

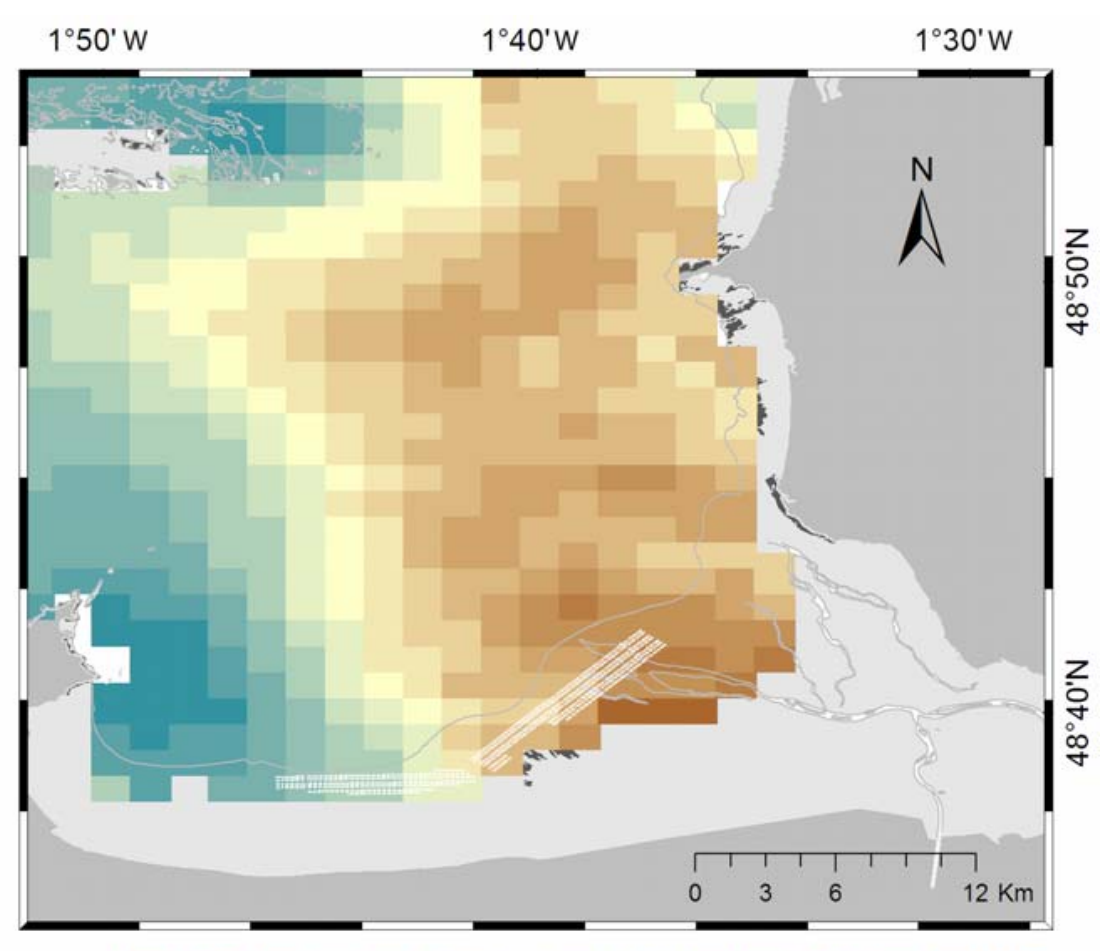

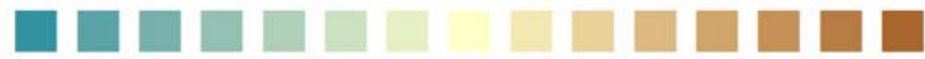

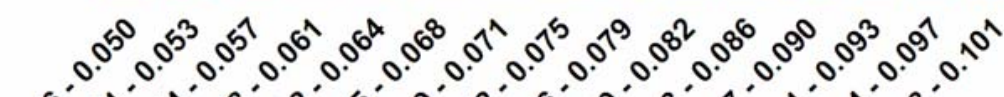

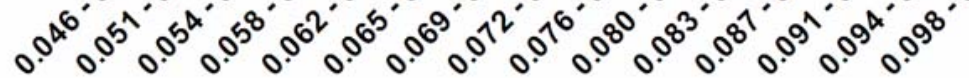




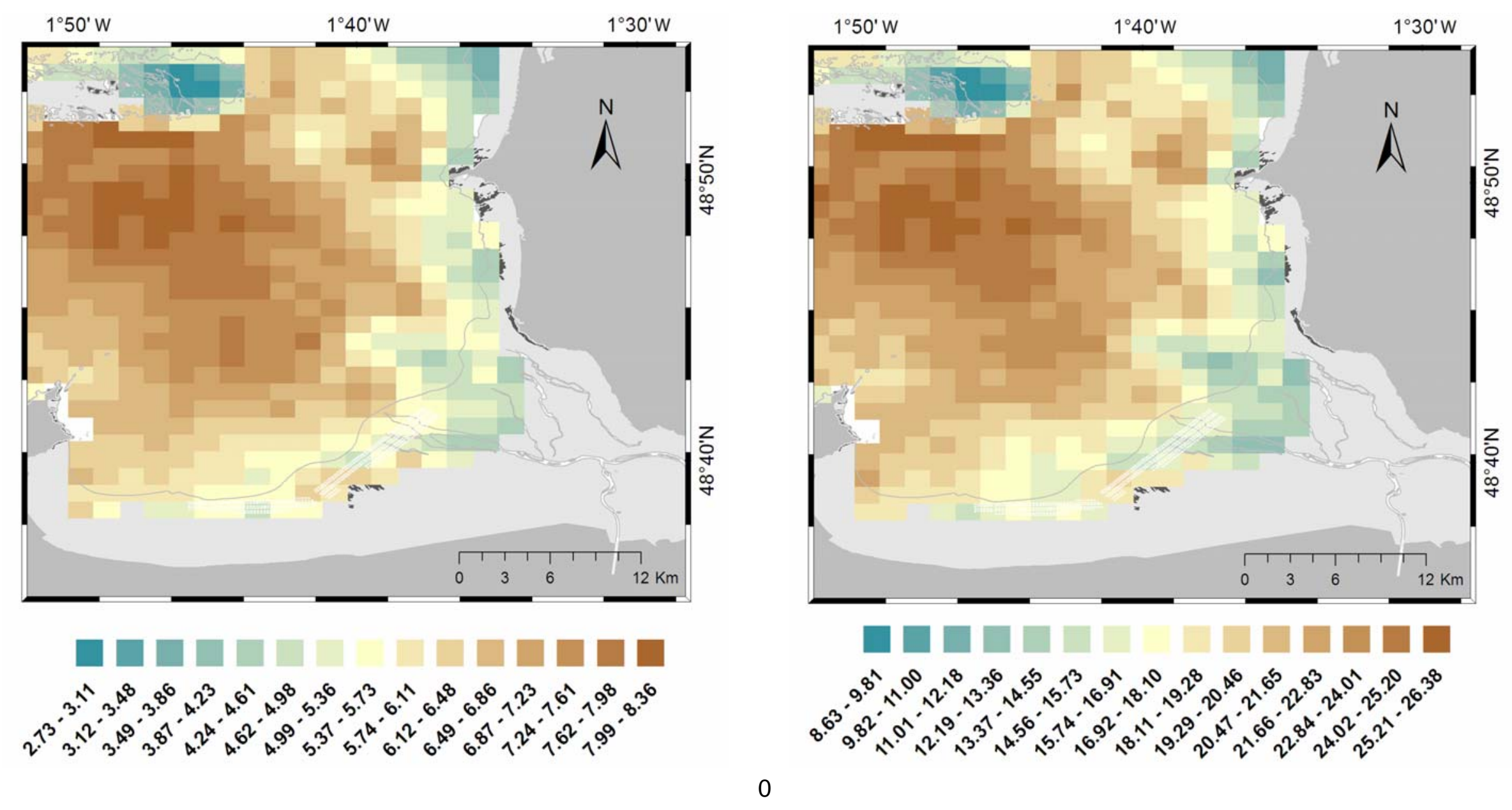

